\title{
RELAKSASI FASILITAS TIDAK DIPUNGUT CUKAI MMEA KADAR RENDAH DIKEMAS UNTUK PENJUALAN ECERAN
}

\author{
Muh. Sutartib ${ }^{1}$, Aditya Subur Purwana ${ }^{2}$ \\ ${ }^{1}$ Pemeriksa Bea dan Cukai Madya, Direktorat Jenderal Bea dan Cukai \\ ${ }^{2}$ Jurusan Kepabeanan dan Cukai, Politeknik Keuangan Negara STAN \\ E-mail: adityasp@pknstan.ac.id
}

\section{INFORMASI ARTIKEL}

Tanggal masuk

[07-03-2021]

Revisi

[29- 03-2021]

Tanggal terima

[21-05-2021]

\begin{abstract}
ABSTRAK:
Perdagangan minuman yang mengandung etil alkohol (MMEA) kadar rendah (kombukha dan kefir) akhir-akhir ini semakin masif. UU Cukai menyatakan MMEA dalam kadar berapa pun merupakan barang kena cukai (BKC). Kombukha (kombucha) dan kefir sebagian besar dihasilkan industri skala rumah tangga, namun dikemas untuk penjualan eceran. Dalam UU Cukai terdapat fasilitas tidak dipungut cukai sesuai kriteria. Penelitian ini bertujuan untuk menganalisis posisi MMEA kadar rendah, terutama hubungannya dengan implementasi UU Cukai di lapangan. Metode yang digunakan adalah kualitatif-interpretatif, dengan data/pengamatan selama tahun 2020-2021. Data sekunder yang digunakan berupa jumlah penjualan kombukha dan kefir yang bersumber pada marketplace Indonesia dengan jenis data kuantitatif skala rasio. Hasil analisis menunjukkan bahwa kombukha dan kefir dikemas untuk penjualan eceran sehingga tidak termasuk kriteria fasilitas tidak dipungut cukai. Solusi dalam jangka pendek untuk melegalkan usaha pembuat MMEA kadar rendah adalah relaksasi ketentuan tentang tidak dipungut cukai sesuai best practice internasional. Selain itu, selaras dengan Fatwa MUI yang menyatakan bahwa minuman hasil fermentasi yang mengandung alkohol dengan kadar kurang dari $0,5 \%$, hukumnya halal jika secara medis tidak membahayakan. Solusi jangka panjang adalah merekonstruksi kembali pasal-pasal dalam UU Cukai yang berkaitan dengan definisi MMEA, cukai tidak dipungut maupun pembebasan cukai melalui amandemen UU Cukai.
\end{abstract}

Kata Kunci: barang kena cukai, kefir, kombucha, MMEA, tidak dipungut cukai. 
Keywords: Alcoholic Beverages, Excisable Goods, Kefir, Kombucha, Unimposing of the Excise.

\section{PENDAHULUAN}

Seperti yang telah kita ketahui, minuman beralkohol merupakan objek cukai di berbagai negara. Demikian pula di Indonesia, minuman jenis ini ditetapkan sebagai barang kena cukai (BKC) yang disebut sebagai minuman yang mengandung etil alkohol (MMEA). Salah satu cara untuk membuat MMEA adalah melalui proses fermentasi bahan-bahan hasil pertanian atau tanaman terutama bahan-bahan yang mengandung gula atau karbohidrat.

Sebagai negara dengan penduduk mayoritas muslim, berbicara secara terbuka mengenai minuman beralkohol merupakan hal yang cukup sensitif. Regulasi pendirian pabrik, importasi, distribusi serta pelabelan terkesan sengaja dibuat rumit, baik dari sisi persyaratan maupun perizinan dengan melibatkan beberapa institusi pemerintah pusat maupun pemerintah daerah.

Mengonsumsi minuman beralkohol dipercaya memiliki beberapa manfaat, tetapi juga menimbulkan banyak kerugian sehingga dalam Agama Islam konsumsi minuman yang memabukkan (misalnya minuman beralkohol) termasuk kegiatan yang diharamkan. Minuman beralkohol merupakan minuman yang bersifat addictive/menimbulkan efek ketagihan sehingga hampir di seluruh dunia peredarannya dikendalikan. Salah satu cara mengendalikannya adalah dengan cara mengenakan cukai. Cnossen (2005) menyebutkan bahwa pengenaan cukai salah satunya bertujuan untuk mengurangi konsumsi dan mengurangi efek eksternalitas.

Beberapa manfaat yang diperoleh dari konsumsi minuman beralkohol dengan jumlah terukur/moderate antara lain mengurangi resiko penyakit jantung, mengurangi risiko terkena penyakit diabetes, dan mengurangi risiko stroke. Sebaliknya, kerugian mengonsumsi minuman beralkohol secara berlebih antara lain meningkatkan risiko kesehatan, misalnya terkena penyakit tertentu (termasuk kanker payudara dan kanker mulut, tenggorokan, kerongkongan, dan hati), kerusakan pankreas, kematian mendadak jika sudah menderita penyakit kardiovaskular, tekanan darah tinggi, cedera serius atau kematian yang tidak disengaja, bunuh diri, kerusakan otak serta beberapa penyakit serius lainnya (Brent A, 2020).

Minuman beralkohol dengan kadar rendah sebenarnya cukup banyak beredar di masyarakat, terutama yang dibuat 
secara tradisional dengan kemasan sederhana misalnya minuman berbahan dasar tape ketan, serta nira yang diperoleh dari getah tandan bunga pohon kelapa, aren, atau lontar.

Selain minuman beralkohol tradisional di atas, akhir-akhir ini banyak dijumpai penjualan secara online minuman kesehatan dengan kandungan etil alkohol rendah dengan nama teh fermentasi/kombukha (kombucha) dan susu fermentasi (kefir). Kedua produk tersebut dijual secara eceran dengan kemasan yang dapat dikatakan tidak sederhana lagi apabila dilihat dari kaca mata UU Cukai (UU Nomor 11 Tahun 1995 sebagaimana telah diubah dengan UU Nomor 39 Tahun 2007).

Kombukha merupakan minuman mengandung alkohol dalam kadar rendah, sehingga akan menjadi perhatian khusus bagi orang-orang sedang hamil dan anak kecil. Secara medis, orang hamil disarankan untuk menjauhkan dari alkohol untuk menghindari risiko gangguan spektrum alkohol pada janin yang membahayakan bayi. Alkohol juga dapat menyebabkan terjadinya keracunan pada anak-anak terutama balita, yang menyebabkan gula darah rendah (hipoglikemia) (McIntyre \& Sik Jang, 2020).
Gambar I.1 Contoh Penjualan Kombukha

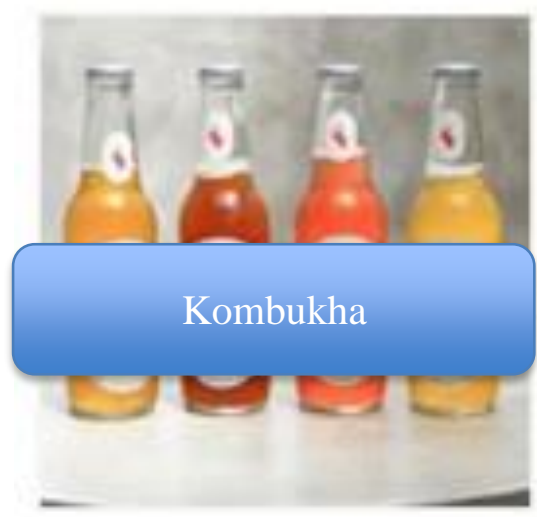

Sumber: marketplace, tokopedia

Gambar I.2 Contoh Penjualan Kefir

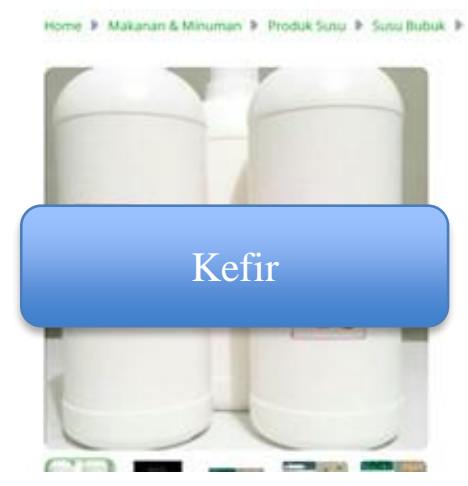

Sumber: marketplace, tokopedia

Apabila berpatokan secara tekstual kepada UU Cukai dalam mendefinisikan apa itu MMEA dan cara mengemasnya ketika dijual, kombukha dan kefir merupakan BKC sehingga produksi, distribusi serta pemasarannya seharusnya tunduk pada UU Cukai.

Minuman fermentasi seperti kombukha dan kefir saat ini banyak diteliti di kalangan perguruan tinggi di Indonesia, 
baik cara pembuatannya, kandungan gizinya maupun efek konsumsinya bagi kesehatan. Skala produksi kedua produk tersebut sebagian besar masih dalam skala rumah tangga dan belum ada yang mendapatkan registrasi dari Badan POM, kecuali satu produk berbentuk bubuk. Badan POM sudah mengeluarkan izin untuk produk yang mengandung kombukha atau kefir yang peruntukannya bukan sebagai minuman (misalnya untuk kosmetik). Badan POM sudah selesai melakukan kajian atas minuman kombukha, tetapi untuk perizinan masih status quo.

Tujuan penelitian ini adalah menganalisis posisi minuman yang mengandung etil alkohol dengan kadar rendah (misalnya kombukha dan kefir) dikemas untuk dijual eceran, terutama hubungannya dengan implementasi UU Cukai di lapangan.

Hasil dari analisis ini diharapkan dapat digunakan sebagai referensi pengambil kebijakan dalam pengambilan keputusan atas fenomena maraknya perdagangan minuman mengandung etil alkohol dengan kadar rendah dan dikemas untuk penjualan eceran.

Beberapa penelitian yang sudah ada di Indonesia, tetapi belum terkait dengan cukai, yaitu: a. cara pembuatan, kandungan gizi maupun efek konsumsi bagi kesehatan, oleh Devita, Risqiati, \& Pramono (2019), Pratiwi, Elfita \& Aryawati (2011);

b. terkait dengan pangan fungsional oleh Khamidah \& Antarlina (2020);

c. terkait minuman fermentasi menyegarkan oleh Balai Besar Penelitian dan Pengembangan Pascapanen Pertanian (2007).

Sampai saat ini di Indonesia belum ada kajian terpublikasi yang membahas minuman fermentasi dengan kadar etil alkohol rendah, seperti kombukha dan kefir yang berkaitan dengan aspek cukai, baik dilihat dari sisi administrasi maupun penegakan hukumnya. Hal ini dimungkinkan karena masyarakat memang tidak mengetahui bahwa minuman jenis tersebut seharusnya termasuk barang kena cukai atau karena mereka beranggapan bahwa minuman tersebut dikategorikan sebagai minuman beralkohol tradisional seperti halnya minuman yang berasal dari air tape, tuak atau minuman sejenis lainnya,

Referensi mengapa minuman dengan kadar etil alkohol rendah (kurang dari $0,5 \%)$ tidak dikategorikan sebagai barang kena cukai bisa dilihat di UU Cukai berbagai negara, misalnya menurut UU 
Cukai Kanada/Excise Act 2001. UU tersebut mendefinisikan minuman alkohol hasil proses penyulingan/spirits sebagai setiap barang yang mengandung etil alkohol absolut lebih dari 0,5\% menurut volumenya selain dari bir, anggur, cuka, alkohol yang dinaturasi dan alkohol yang didenaturasi khusus. Anggur/wine didefinisikan sebagai minuman "mengandung etil alkohol absolut lebih dari $0,5 \%$ menurut volumenya tetapi tidak lebih dari 22,9\%" yang diperoleh melalui fermentasi alkohol produk pertanian, tanaman, produk tanaman selain bijibijian. Termasuk dalam kategori anggur adalah minuman yang diperoleh dari seluruhnya atau sebagian dari turunan produk pertanian, tanaman maupun produk tanaman seperti minuman sake.

Negara-negara di lingkungan Uni Eropa juga hanya mengenakan cukai untuk minuman beralkohol dengan kadar etil alkohol absolut di atas $0,5 \%$ menurut volumenya. Hal ini bisa dilihat pada Excise Duty Tables yang diterbitkan oleh European Commission, Directorate Taxation and Customs Union.

Apabila kita melihat Ordonansi Cukai Alkohol Sulingan Stbl 1924 No.351 Bab I Pasal 1 maka dapat diketahui bahwa alkohol sulingan dengan kadar kurang dari $5 \%$ menurut volumenya dikecualikan sebagai barang kena cukai. Penulis menduga hal ini dimaksudkan untuk kemudahan administrasi karena pada saat itu peralatan analisis untuk menguji kandungan alkohol belum sesensitif peralatan yang ada saat ini.

Dengan membuat regulasi yang jelas mengenai kadar minimal kandungan etil alkohol dalam minuman beralkohol yang wajib dikenakan cukai akan memudahkan DJBC untuk mengadministrasikan maupun melakukan penegakan hukum. Di samping itu, dengan peraturan yang jelas dan transparan diharapkan para produsen minuman kefir, kombukha maupun minuman sejenis dapat berusaha dengan tenang tanpa ada kekhawatiran bahwa bisnisnya akan dianggap sebagai bisnis yang ilegal.

\section{KAJIAN LITERATUR}

\subsection{Cukai atas minuman beralkohol}

Menurut Cnossen (2005), cukai atau excise merupakan jenis pajak yang tertua di dunia yang dikenakan secara selektif atas barang atau jasa. Pembeda cukai dengan pajak konsumsi lain seperti pajak pertambahan nilai (PPN) atau pajak penjualan adalah selektivitas dalam cakupan, bertujuan untuk maksud tertentu, menggunakan pengukuran kuantitatif dalam menentukan kewajiban pajaknya. 
Tujuan pengenaan cukai adalah untuk mendapatkan penerimaan, mencerminkan biaya eksternal, mengurangi konsumsi dan untuk mengenakan biaya atas penggunaan barang dan jasa disediakan pemerintah.

Alasan pengenaan cukai atas minuman beralkohol pada umumnya berakitan dengan eksternalitas negatif akibat konsumsi yang berlebihan.

Konsumsi alkohol yang berlebihan adalah penyebab kematian ketiga di Amerika Serikat dengan jumlah per tahun sekitar 79.000 orang. Konsumsi alkohol yang berlebihan berkontribusi pada berbagai masalah kesehatan dan sosial, termasuk cedera yang tidak disengaja (misalnya, cedera akibat kecelakaan kendaraan bermotor); bunuh diri; pembunuhan; sirosis hati; kanker gastrointestinal; vandalisme; dan hilangnya produktivitas. Konsumsi alkohol oleh peminum di bawah umur juga berkontribusi kepada tiga penyebab utama kematian di kalangan remaja (cedera yang tidak disengaja, bunuh diri, dan pembunuhan) (Elder et al., 2010).

\subsection{MMEA menurut UU Cukai}

Sesuai Pasal 4 ayat (1) huruf b UU Cukai, minuman yang mengandung etil alkohol dalam kadar berapa pun, dengan tidak mengindahkan bahan yang digunakan dan proses pembuatannya, termasuk konsentrat yang mengandung etil alkohol, merupakan BKC.

Selanjutnya, menurut penjelasan ayat ini diterangkan bahwa yang dimaksud dengan minuman yang mengandung etil alkohol adalah semua barang cair yang lazim disebut minuman yang mengandung etil alkohol yang dihasilkan dengan cara peragian, penyulingan, atau cara lainnya, antara lain bir, shandy, anggur, gin, wiski, dan yang sejenis. Yang dimaksud dengan konsentrat yang mengandung etil alkohol adalah bahan yang mengandung etil alkohol yang digunakan sebagai bahan baku atau bahan penolong dalam pembuatan minuman yang mengandung etil alkohol.

Dari uraian di atas dapat disimpulkan bahwa apa pun jenis minumannya, apabila mengandung etil alkohol, berapa pun kadarnya, seberapa pun kecilnya, minuman tersebut merupakan barang kena cukai (BKC) sehingga konsumsi maupun peredarannya harus tunduk pada UU Cukai.

\subsection{Minuman Beralkohol menurut Harmonized System}

Menurut catatan 3 Bab 22 Konvensi Harmonized System (HS) maupun dalam Buku Tarif Kepabeanan Indonesia (Kementerian Keuangan, 2017), minuman dianggap tidak mengandung alkohol 
apabila dalam minuman tersebut kandungan alkoholnya tidak melebihi $0,5 \%$ menurut volumenya. Pengukuran kandungan alkohol atas minuman ini dilakukan pada temperatur $20^{\circ} \mathrm{C}$. Konsekuensi dari definisi ini, semua minuman dengan kandungan etil alkohol kurang dari $0,5 \%$-v/v dianggap sebagai non-alcoholic beverages. Salah satu contoh dari produk ini adalah nonalcoholic beer, sekalipun mengandung alkohol, karena kandungannya kurang dari 0,5\% klasifikasi menurut HS termasuk dalam golongan minuman ringan (soft drink).

\subsection{Kombukha (Kombucha)}

Kombu dan cha merupakan asal kata kombucha. Asal minuman kombukha diduga dari China. Dari negeri China, penyebarannya mengikuti jalur perdagangan dan akhirnya tersebar ke berbagai penjuru dunia. Di China, kombukha lebih dikenal dengan istilah teh Manchuria (https://en.wikipedia.org /wiki/Kombucha).

Teh kombukha merupakan minuman fermentasi yang dibuat dengan teh, gula, bakteri dan ragi. Teh kombukha dibuat dengan menambahkan koloni ke gula dan teh, dan membiarkan campuran tersebut berfermentasi. Cairan yang dihasilkan mengandung cuka, vitamin $\mathrm{B}$ dan sejumlah senyawa kimia lainnya (Brent A, 2020).

Kombukha memiliki efek protektif terhadap aterosklerosis dan penyakit kardiovaskular, kanker dan mutasi gen, berdampak positif bagi penderita diabetes dan gagal ginjal, dan merupakan aktivitas antibakteri dan antivirus (Dufresne \& Farnworth, 1999).

Khamidah \& Antarlina (2020) menulis bahwa kombukha bermanfaat bagi tubuh sebagai antioksidan dan antidiabetik, antibakteri, memperbaiki mikroflora usus, meningkatkan ketahanan tubuh dan menurunkan tekanan darah, menurunkan kolesterol, mencegah penyakit kardiovaskular, mengurangi inflamasi, dan mestimulasi sistem imun tubuh.

Menurut definisi dari Alcohol and Tobacco Tax and Trade Bureau (TTB), Departemen Keuangan, Amerika Serikat istilah kombukha umumnya mengacu pada minuman fermentasi yang dihasilkan dari campuran teh dan gula yang direndam, dikombinasikan dengan kultur strain ragi dan bakteri. Beberapa produk kombukha juga memiliki rasa jus buah atau rasa lain yang ditambahkan selama produksi. Kombinasi gula dan ragi memicu fermentasi, yang dapat menghasilkan kombukha dengan kandungan alkohol bisa mencapai 0,5\% 
Vol. 5, No. 1, 2021

atau lebih berdasarkan volume

(https://www.ttb.gov/kombucha).

Tabel II.1 Perlakuan Kombukha berdasarkan TTB

\begin{tabular}{|c|c|}
\hline $\begin{array}{l}\text { Kombucha is AT OR ABOVE } 0.5 \% \text { alcohol by volume } \\
\text { at any time } \\
\text { TTB Regulations } \\
\text { DO APPLY } \\
\text { - Visit our Kombucha Information and Resources for TTB } \\
\text { requirements, and other information about kombucha } \\
\text { testing, production, distribution, and labeling. } \\
\text { - All kombucha also must comply with any applicable state } \\
\text { and local requirements. }\end{array}$ & $\begin{array}{l}\text { Kombucha is NEVER at or above } 0.5 \% \text { alcohol by } \\
\text { volume during production, at time of bottling, or after } \\
\text { bottling } \\
\text { TTB Regulations } \\
\text { DO NOT APPLY }\end{array}$ \\
\hline
\end{tabular}

Sumber: https://www.ttb.gov/kombucha

\subsection{Kefir}

Minuman susu fermentasi kefir mirip dengan yogurt encer atau ayran yang terbuat dari biji kefir, jenis kultur simbiosis mesofilik tertentu (https://en.wikipedia.org/wiki/Kefir).

Kefir umumnya digunakan dalam pengolahan produk ternak tradisional berupa susu sebagai substrat. Perkembangan terkini menggunakan kultur kefir untuk memfermentasi substrat lain seperti jus buah, yang produknya dikenal sebagai kefir buah. Ada 2 jenis fermentasi kefir, yaitu kefir susu dan kefir air. Kefir susu terbuat dari susu sapi, susu kambing atau domba dengan ditambahkan starter kefir berupa butiran/biji kefir, sedangkan kefir air terbuat dari campuran biji kefir dengan air, buah-buahan kering seperti kismis, potongan kecil jeruk nipis, dan gula pasir.
Kefir mungkin awalnya dibuat dari susu unta, tetapi donor susu saat ini umumnya adalah sapi. Secara tradisional, kefir memiliki kandungan alkohol sekitar 2,5 persen. (Orang Rusia menggunakannya sebagai obat untuk mengatasi mabuk). Saat dituang, dapat mendesis seperti bir. Karena laktosa adalah gula yang dipecah dalam fermentasi, orang yang tidak toleran laktosa sering kali dapat menoleransi kefir.

Seperti juga kombukha, beberapa tulisan terpublikasi juga menyatakan bahwa kefir memiliki beberapa manfaat bagi kesehatan. John \& Deeseenthum (2015) mengatakan bahwa kefir memiliki efek antimikroba, bersifat antikarsinogenik dan memiliki kegunaan untuk menghambat pertumbuhan tumor, memiliki efek penurun kolesterol, dapat 
meningkatkan toleransi laktosa, serta memiliki sifat penyembuhan luka. Untuk wanita hamil, kefir dapat mendorong penyerapan nutrisi, meningkatkan kekebalan, membantu tubuh menyesuaikan diri dengan perubahan hormonal dan mencegah infeksi seperti pertumbuhan jamur yang berlebih. Selain itu, konsumsi kefir oleh wanita hamil dapat mencegah pertumbuhan berlebih dari bakteri yang disebut grup $B$ Beta Streptococcus.

Kefir dipercaya sebagai minuman bergizi tinggi dengan kandungan lakstosa yang lebih rendah daripada yang ada dalam susu murni. Kefir bermanfaat bagi individu yang tidak tahan terhadap laktosa/gula susu, karena laktosanya telah dicerna menjadi glukosa dan galaktosa oleh enzim laktase dari mikrobia dalam biji kefir. Selain itu, sebagian masyarakat percaya bahwa kefir dapat menyembuhkan beberapa penyakit metabolism, seperti diabetes melitus, asma, dan jenis tumor tertentu, walaupun penelitian secara ilmiah tentang hal itu belum dilakukan (Balai Besar Penelitian dan Pengembangan Pascapanen Pertanian, 2007).

\subsection{Terminologi alcohol free dalam minuman}

Di Eropa, suatu produk minuman dikatakan sebagai alcohol free apabila kandungan alkohol di minuman tersebut lebih rendah dari $0,5 \%$ menurut volumenya. Namun, di Inggris kriteria tersebut lebih kecil lagi, yaitu di bawah $0,05 \%$. Kriteria tersebut masih bisa berubah karena batas kandungan 0,05\% sering menimbulkan kebingungan di kalangan konsumen. Di Inggris, kandungan alkohol di bawah 0,05\% dinamakan "alcohol free", sedangkan di bawah $0,5 \%$ dilabeli de-alcoholized (Arthur, 2018).

\subsection{Fatwa Majelis Ulama Indonesia tentang produk makanan dan minuman yang mengandung alkohol/etanol}

Majelis Ulama Indonesia (MUI) melalui Fatwa Nomor 10 Tahun 2018 memberikan penegasan bahwa tidak semua minuman yang mengandung alkohol merupakan minuman yang haram. Minuman yang dihasilkan dari proses fermentasi dinyatakan halal sekalipun mengandung etil alkohol (dengan ketentuan secara medis tidak membahayakan), meliputi:

- Produk minuman hasil fermentasi yang mengandung alkohol/etanol kurang dari $0,5 \%$;

- Produk minuman bukan hasil fermentasi yang mengandung alkohol 
atau etanol kurang dari $0,5 \%$ yang bukan dari khamr, seperti minuman ringan yang ditambahkan perisa yang mengandung alkohol atau etanol.

\section{METODE PENELITIAN}

Metode penelitian yang digunakan adalah metode kualitatif-interpretatif melalui beberapa tahapan, yaitu:

1. Kondisi saat ini yang bertujuan untuk memetakan kondisi saat ini sebagai baseline. Data yang dibutuhkan adalah data sekunder yang diperoleh dari studi pustaka dan sumber lain, misalnya data jumlah dan nama barang yang dijual secara online.

2. Identifikasi tujuan dan kebutuhan yang bertujuan untuk mengetahui maksud dan tujuan dari usulan pembuatan regulasi yang sesuai dengan kondisi lingkungan yang ada, tanpa harus melanggar peraturan perundangundangan yang ada.

3. Benchmarking, melihat praktik di negara lain dalam memperlakukan produk minuman dengan kadar etanol rendah.

Data/pengamatan dilaksanakan untuk periode tahun 2020 s.d. 2021, yaitu data sekunder berupa jumlah penjualan kombukha dan kefir yang bersumber pada marketplace Indonesia. Jenis data yang terkumpul merupakan data kuantitatif dengan skala rasio.

Berdasarkan uraian tersebut, framework penelitian ini adalah sebagai berikut:

Gambar III.1. Framework Penelitian 
Vol. 5, No. 1, 2021

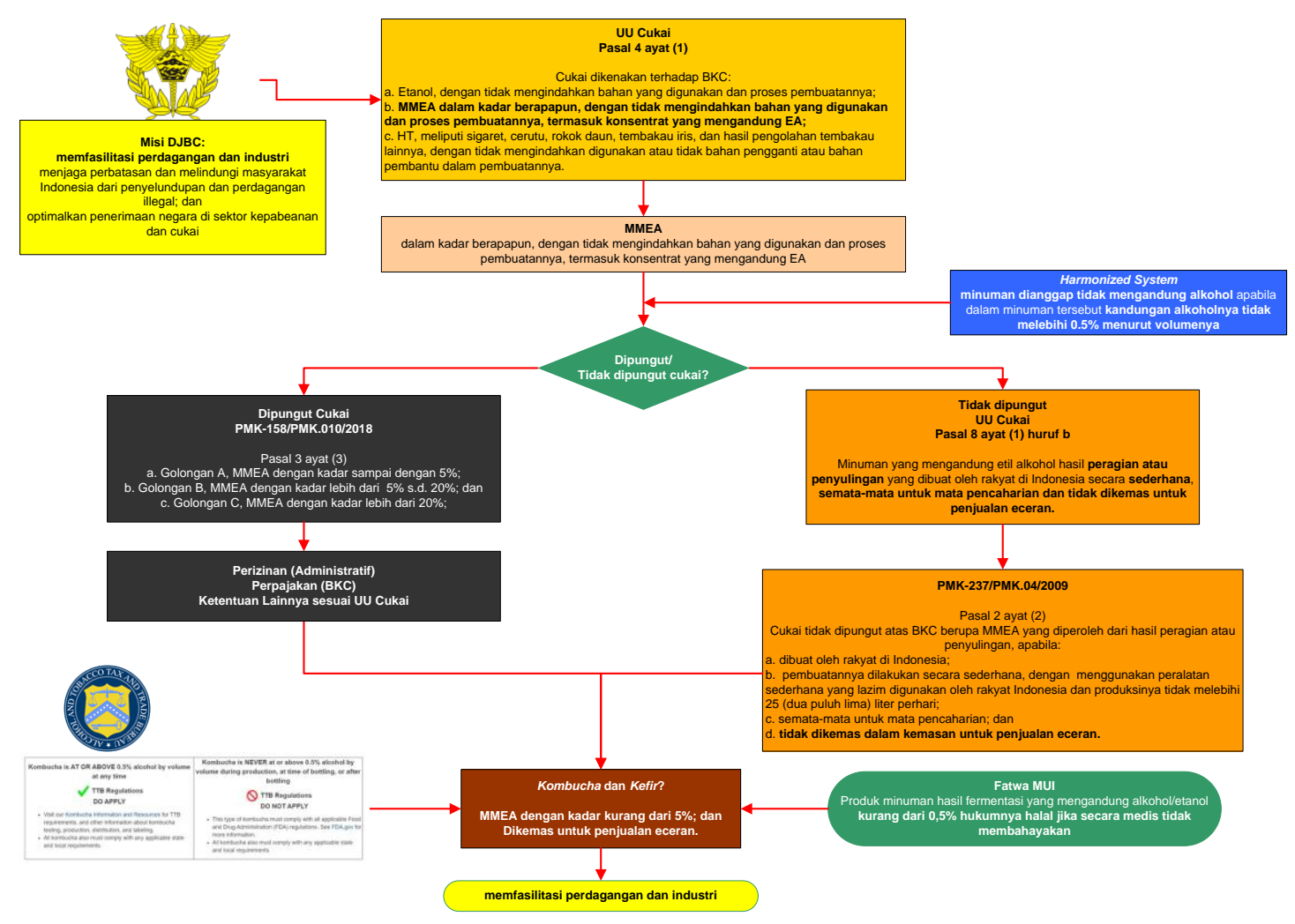

Sumber: diolah penulis

\section{HASIL DAN PEMBAHASAN}

\subsection{Status/perlakuan kombukha di negara lain}

Status kombukha sebagai barang kena cukai diperdebatkan di beberapa negara karena kandungan etil alkohol tidak konsisten selama penyimpanan. Dalam praktiknya, kadar etil alkohol bisa mencapai $1,5 \%$ sehingga dalam international best practise sudah bisa dikategorikan sebagai minuman beralkohol. Negara yang sudah mengatur status kombukha secara jelas adalah Amerika Serikat melalui regulasi yang dikeluarkan oleh Alcohol and Tobacco Tax and Trade Beureau (TTB). Menurut
Undang-Undang Federal, jika kandungan alkohol dalam kombukha $0,5 \%$ atau lebih berdasarkan volume, kapan pun selama produksi, saat dibotolkan, atau kapan saja setelah pembotolan, kombukha termasuk minuman beralkohol dan harus tunduk pada peraturan TTB.

\subsection{Peta perdagangan kombukha dan} kefir di Indonesia.

Minuman beralkohol dengan kadar EA rendah saat ini banyak diperjualbelikan di Indonesia terutama secara online (dikemas untuk penjualan eceran). Berdasarkan pencarian melalui internet, tanggal 6 Maret 2021 dijumpai puluhan merk 
kombukha dan kefir yang dijual dengan berbagai variasi harga dan berbagai variasi volume kemasan/paket. Berikut ini daftar jumlah produk baik yang bermerk maupun tanpa merk yang terlacak melalui search engine google pada penjualan secara online per tanggal 6 Maret 2021 atas kedua komoditi tersebut:

Tabel IV.1. Penjualan Kombukha dan Kefir secara online

\begin{tabular}{|l|c|c|}
\hline Marketplace & $\begin{array}{c}\text { Kombukha } \\
\text { (Kombucha) }\end{array}$ & Kefir \\
\hline - Tokopedia & 447 & 859 \\
- Bukalapak & 27 & 149 \\
- Lazada & 182 & 203 \\
- Shopee & 224 & 154 \\
- Bibli & 48 & 12 \\
\hline
\end{tabular}

Sumber: marketplace

Dari Tabel IV.1, penjualan kombukha dan kefir sebagai minuman mengandung ethanol dengan kadar rendah sudah cukup masif sehingga perlu peranan pemerintah untuk membuat regulasi. Intinya, perlu relaksasi peraturan atas usaha ini sehingga penjualannya merupakan penjualan yang tidak melanggar hukum.

\subsection{Kandungan etil alkohol pada kombukha dan kefir}

Kandungan etanol dalam kefir pernah diteliti oleh beberapa peneliti di Indonesia, salah satunya oleh Devita, Risqiati \& Pramono (2019). Berdasarkan penelitian ini disimpulkan bahwa kadar alkohol dalam kefir susu kambing dipengaruhi oleh lamanya fermentasi. Fermentasi susu kambing selama 24 jam, 36 jam, 48 jam dan 60 jam akan menghasilkan kadar alkohol (dalam \%-volume) masing masing $0,304 \pm 0,313,0,532 \pm 0,258,0,692 \pm$ 0,270 dan $0,878 \pm 0,210$.

Dari data ini kita sebenarnya bisa mengatur kadar etil alkohol dalam kefir dengan cara menghentikan proses fermentasi pada waktu tertentu, ketika kadar etil alkoholnya sudah sesuai yang kita kehendaki.

Menurut Abou Ayana \& Saber (2016), untuk mengurangi kadar alkohol dalam kefir sehingga kadar alkoholnya sesuai yang dikehendaki, tergantung pada jenis susu, ukuran inokulasi (inokulasi merupakan proses pemindahan bakteri dari media lama ke media yang baru), serta temperatur inkubasi. Sebagai contoh dengan ukuran inokulasi 2\%, kadar alkohol rata-rata dari kefir yang berasal dari susu kerbau pada temperatur inkubasi $24^{\circ} \mathrm{C}$ adalah $0,180 \%$ sedangkan apabila temperatur inkubasinya $28^{\circ} \mathrm{C}$ maka kadar alkohol rata-ratanya menjadi 0,194\%. Untuk ukuran inokulasi $4 \%$ kandungan alkohol rata-rata pada dua temperatur inkubasi seperti tersebut di atas masingmasing sebesar $0,187 \%$ dan $0,207 \%$. 
Penelitian ini juga mengindikasikan bahwa kandungan etil alkohol dalam kefir dapat kita kendalikan.

McIntyre \& Sik Jang (2020), melakukan penelitian terhadap kandungan etil alkohol dalam berbagai merk kombukha yang dipasarkan dengan mengambil sampel yang berasal dari restoran, grosir maupun di tempat penjualan eceran. Kadar etil alkohol yang diperoleh sangat variatif untuk tiap merk, mulai dari kadar etil alkohol rata-rata $0,04 \%$ sampai dengan rata-rata $3,07 \%$. Pemerintah British Columbia mensyaratkan kombukha yang diperjualbelikan harus memiliki kadar etil alkohol kurang dari $1 \%$. Hasil penelitian menyimpulkan sebanyak $68 \%$ produk memenuhi syarat (kadar alkohol kurang dari 1\%), sebanyak $25,3 \%$ produk memiliki kadar etil alkohol antara $1 \%$ sampai $2 \%$ dan sisanya $(6,2 \%)$ memiliki kadar etil alkohol di atas $2 \%$.

Pengaruh waktu fermentasi terhadap kandungan etil alkohol dalam kombukha, antara lain pernah diteliti oleh Pratiwi, Elfita \& Aryawati (2011). Hasil dari penelitian tersebut menunjukkan bahwa makin lama fermentasi cairan kombukha yang berasal dari Sargassum sp. maka kandungan etil akoholnya akan naik, lalu akan turun lagi seiring lamanya proses fermentasi. Fermentasi selama 4 hari akan menghasilkan etil alkohol sebesar 0,2973 $\%$. Dengan fermentasi selama 8 hari dan 12 hari, kadar etil alkohol akan naik masing-masing menjadi $0,4683 \%$ dan $0,6209 \%$. Pengamatan proses fermentasi pada hari ke-16 ternyata kadar etil alkoholnya justru turun menjadi $0.4240 \%$.

Dari sini dapat disimpulkan kadar etil alkohol dalam kombukha dapat diatur proses fermentasinya, yang paling utama adalah menghentikan proses fermentasi ketika kombukha akan dijual secara eceran dalam kemasan.

Khusus untuk kombukha, Direktorat Teknis dan Fasilitas Cukai, DJBC pada tahun 2019 (DJBC, 2020) pernah mengirim 4 buah sampel dengan merk berbeda ke Balai Pengujian dan Identifikasi Barang (BPIB) Jakarta atas minuman kombukha untuk diteliti kandungan etil alkoholnya. Keempat sampel tersebut memiliki kadar etil alkohol masing-masing sebesar 0,32\%, $0,27 \%, 0,41 \%$ dan $0,25 \%$.

\subsection{Regulasi tidak dipungut cukai menurut UU Cukai}

Fasilitas tidak dipungut cukai dalam UU Cukai tercantum dalam Pasal 8. Khusus untuk minuman yang mengandung etil alkohol diatur dalam ayat (1) huruf b yang menyatakan bahwa tidak 
dipungut cukai atas minuman yang mengandung etil alkohol hasil peragian atau penyulingan yang dibuat oleh rakyat di Indonesia secara sederhana, semata mata untuk pencaharian dan tidak dikemas untuk penjualan eceran.

Untuk menindaklanjuti implementasi Pasal 8 UU Cukai, Menteri Keuangan telah menerbitkan PMK Nomor 237/PMK.04/2009 tentang Tidak Dipungut Cukai (Kementerian Keuangan, 2009). Salah satu isi kentuannya adalah penjabaran lebih detail dari persyaratan agar minuman yang mengandung etil alkohol hasil peragian atau penyulingan mendapatkan fasilitas tidak dipungut cukai, yaitu dibuat oleh rakyat di Indonesia; pembuatannya dilakukan secara sederhana, dengan menggunakan peralatan sederhana yang lazim digunakan oleh rakyat Indonesia dan produksinya tidak melebihi 25 (dua puluh lima) liter perhari; semata-mata untuk mata pencaharian; dan tidak dikemas dalam kemasan untuk penjualan eceran.

Empat persyaratan di atas merupakan persyaratan yang bersifat kumulatif, sehingga salah satu saja tidak terpenuhi maka kriteria sebagai barang kena cukai yang tidak dipungut cukai menjadi gugur, sehingga kefir atau kombukha yang dijual secara eceran seharusnya tunduk pada UU Cukai.

Apabila kita membaca Pasal 8 ayat (2a), kita akan mengetahui bahwa Menteri Keuangan memiliki kewenangan untuk mengubah barang kena cukai yang tidak dipungut cukai sebagaimana dimaksud pada ayat (1). Dengan adanya wewenang Menteri Keuangan ini, terdapat peluang pengusaha minuman beralkohol rendah seperti kefir maupun kombukha untuk tetap menjalankan bisnis/industrinya. Kriteria kadar etil alkohol yang tidak dipungut cukai yang akan dituangkan dalam PMK tentang Tidak Dipungut Cukai yang baru, dapat mengacu pada best practise internasional yang biasanya berpedoman pada konvensi Harmonized System dengan treshold kandungan etil alkohol sebesar $0,5 \%$ menurut volumenya.

Regulasi berupa Peraturan Menteri Keuangan tentang Cukai Tidak Dipungut dengan memasukkan semua minuman yang mengandung etil alkohol rendah (sesuai best practice kandungan di bawah $0,5 \%$ menurut volumenya) yang dikemas untuk penjualan eceran akan membuat kepastian hukum bagi para pengusaha yang bergerak di bidang minuman.

Alternatif regulasi selain mengubah PMK tidak dipungut cukai adalah intervensi melalui tarif cukai MMEA. 
Selama ini tarif cukai MMEA dibagi menjadi tiga golongan, yaitu MMEA Golongan A untuk MMEA dengan kadar EA sampai dengan 5\%, Golongan B untuk MMEA dengan EA di atas 5\% sampai dengan 20\% dan Golongan C untuk MMEA dengan kadar EA di atas $20 \%$. Apabila berpatokan pada PMK Nomor 158/PMK.010/2018 tentang Tarif Cukai Etil Alkohol, Minuman Yang Mengandung Etil Alkohol, dan Konsentrat Mengandung Etil Alkohol (Kementerian Keuangan, 2018) kefir dan kombucha termasuk MMEA Golongan A dengan tarif cukai Rp15.000,00 setiap liternya. Intervensi yang dapat dilakukan pemerintah adalah menetapkan tarif cukai sebesar nol rupiah untuk MMEA Golongan A dengan kadar EA di bawah $0,5 \%$. Kekurangan dari intervensi tarif ini adalah pengusaha kefir maupun kombukha tetap dibebani dokumen perizinan dan administrasi pelaporan yang tidak sederhana sebagai pengusaha barang kena cukai.

Bagi pengusaha berskala rumah tangga, tentu saja beban administrasi akan menjadi persoalan tersendiri. Intervensi pemerintah, dalam hal ini Kementerian Keuangan, akan lebih tepat apabila berupa penetapan MMEA dengan kadar kurang dari $0,5 \%$ sebagai barang kena cukai yang tidak dipungut cukai daripada berupa insentif tarif $0 \%$.

Undang-Undang Cukai yang mengategorikan sebagai minuman mengandung etil alkohol (MMEA) terhadap semua minuman beralkohol dengan kadar etil alkohol berapa pun tanpa batasan yang jelas, sebenarnya tidak bisa diimplementasikan untuk minuman yang memiliki kadar etil alkohol kecil. Apabila pemerintah dapat mengeluarkan regulasi yang mengecualikan minuman beralkohol rendah (kadar EA di bawah 0,5\%) sebagai produk yang wajib bayar cukai, tentu saja regulasi tersebut akan sangat bermanfaat bagi bisnis komoditi minuman lainnya yang memiliki kadar EA setara dengan kefir dan kombukha. Hal ini akan selaras dengan Fatwa MUI yang menyatakan bahwa produk minuman hasil fermentasi yang mengandung alkohol/etanol kurang dari $0,5 \%$ hukumnya halal jika secara medis tidak membahayakan.

Sebenarnya cukup banyak minuman yang mengandung etil alkohol rendah tanpa kita menyadarinya karena dimungkinkan etil alkohol tersebut terbentuk karena fermentasi alamiah atau sebab lain yang tidak disengaja. Salah satu potensi minuman yang terdapat etil alkoholnya, sekalipun kecil (di bawah $0.5 \%)$, adalah minuman kopi yang berasal 
dari kopi instan yang memakai essence maupun flavoring. Dalam pembuatan essence atau flavoring ini sering kali menggunakan bahan pengekstrak berupa etil alkohol dan etil alkohol tersebut tidak hilang seluruhnya dalam produk essence atau flavoring tersebut.

Apabila kita hanya berpatokan pada UU Cukai, minuman tersebut termasuk minuman mengandung etil alkohol atau konsentrat mengandung etil alkohol (untuk minuman bubuk), karena di UU Cukai mengatakan kadar berapa pun.

\section{SIMPULAN DAN SARAN/ REKOMENDASI}

Perdagangan/industri minuman mengandung etil alkohol dengan kadar rendah akhir-akhir ini terjadi semakin massif, terutama yang dijual melalui perdagangan secara online.

Apabila berpedoman pada UU Cukai yang berlaku saat ini, semua minuman mengandung etil alkohol dalam kadar berapa pun merupakan barang kena cukai.

Walapun barang-barang tersebut sebagian besar dihasilkan oleh industri skala rumah tangga, barang-barang tersebut tidak termasuk barang yang mendapat fasilitas tidak dipungut cukai sesuai kriteria yang disebutkan dalam Pasal 8 ayat (1) huruf b UU Cukai. Penyebabnya adalah karena penjualannya sudah dilakukan secara eceran dengan bentuk pengemas yang tidak sederhana.

Solusi jangka pendek untuk melegalkan usaha para pembuat minuman beralkohol berkadar etil alkohol rendah tersebut adalah mengubah Peraturan Menteri Keuangan tentang Tidak Dipungut Cukai dengan cara menambahkan minuman mengandung etil alkohol dengan kandungan etil alkohol kurang dari $0,5 \%$ menurut volumenya, sesuai best practice internasional sebagai salah satu komoditi barang kena cukai yang cukainya tidak dipungut. Hal ini juga selaras dengan Fatwa MUI yang menyatakan bahwa produk minuman hasil fermentasi yang mengandung alkohol/etanol kurang dari 0,5\% hukumnya halal jika secara medis tidak membahayakan (hal ini dapat ditindaklanjuti melalui penelitian/kajian akademis rancangan amandemen UU Cukai).

Penambahan ini diperkenankan karena menurut Pasal 8 ayat (2a) UU Cukai menyebutkan bahwa perubahan barang kena cukai yang tidak dipungut cukai sebagaimana dimaksud ayat (1) ditetapkan oleh Menteri.

Perubahan PMK Nomor 237/PMK.04/2009 tentang Tidak Dipungut Cukai juga akan membantu 
Badan POM untuk mempercepat proses izin edarnya. Badan POM saat ini belum mengeluarkan izin kemungkinan karena status barang-barang tersebut saat ini masih termasuk kategori MMEA Gol. A apabila memakai kaca mata UU Cukai.

Sebelum menambahkan minuman mengandung etil alkohol dengan kadar di bawah 0,5\% sebagai komoditi BKC yang cukainya tidak dipungut, penelitian lanjutan perlu juga dilaksanakan agar kebijakan yang dikeluarkan dapat diterima oleh stakeholder terkait. Penelitian secara komprehensif dapat dilakukan walaupun harus mengeluarkan biaya yang tidak sedikit, misalnya menguji kandungan etil alkohol terhadap semua merk kefir dan kombukha yang beredar di pasaran, mengumpulkan data produsen kefir dan kombukha, serta jumlah produksinya, kemudian menghitung dampak ekonomi serta dampak administrasi apabila kefir dan kombukha dikenakan cukai,

Solusi jangka panjang adalah merekonstruksi kembali pasal-pasal dalam UU Cukai yang berkaitan dengan MMEA maupun pasal-pasal yang berkaitan dengan cukai tidak dipungut maupun pembebasan cukai melalui amandemen UU Cukai. Sebagai contoh dalam UU Cukai saat ini cukai dikenakan atas BKC berupa minuman yang mengandung etil alkohol dengan kadar berapa pun, dengan tidak mengindahkan bahan yang digunakan dan proses pembuatannya. Pengenaan cukai terhadap minuman dengan kadar etil alkohol berapa pun dalam praktiknya tidak bisa diimplementasikan untuk minuman dengan kadar alkohol rendah sehingga untuk kepastian hukum dan kemudahan administrasi/ease of administration melalui amandemen UU Cukai perlu ditetapkan batas bawah kandungan etil alkohol dalam MMEA. Dengan ditetapkannya batas bawah kandungan etil alkohol dalam MMEA maka akan berubah pula pasal-pasal tidak dipungut cukai maupun pembebasan cukai atas MMEA.

\section{DAFTAR PUSTAKA}

Abou Ayana, Ibrahim A. A. \& Saber, Wesam I. A. (2016). Optimization of Milk Type and Physical Factors for Reduction of Alcohol Content in Kefir. Journal: J. Food and Dairy Sci., Mansoura Univ., Vol. 7 (3), March, 2016: 161-166.

Alcohol and Tobacco Tax and Trade Bureau in the United States of America. (2015). http://www.ttb.gov

Arthur, Rachel. (2018). What-exactly - is "alcohol free? Retrieved from https://www.beveragedaily.com/A rticle/2018/05/08/UKconsultation-for-low-and-noalcohol-descriptors on February 2, 2021.

Balai Besar Penelitian dan Pengembangan Pascapanen Pertanian. (2007). 
Kefir, Susu Fermentasi dengan Rasa Menyegarkan. Bogor: Warta Penelitian dan Pengembangan Pertanian Vo. 29, No. 2: 12-14.

Brent A. Bauer, M.D. (2020). What is kombucha tea? Does it have any health benefits? Retrieved from https://www.mayoclinic.org/healt hy-lifestyle/consumerhealth/expert-answers/kombuchatea/faq-20058126 on March 7, 2021

Cnossen, S. (2005). Theory and Practice of Excise Taxation. Smoking, Drinking, Gambling, Polluting, and Driving. Oxford University Press.

Devita, M., Risqiati, A. \& Pramono, Y.B. (2019). Pengaruh Lama Fermentasi Terhadap kadar Alkohol, Lemak, Nilai pH, dan Total BAL Kefir Prima Susu Kambing. Fakultas Pertanian dan Peternakan, Universitas Diponegoro, Semarang. Dufresne, C. \& Farnworth, E. (1999). Tea, Kombucha, and health: a review. Journal: Food Research International 33 (2000) 409-42.

Direktorat Jenderal Bea dan Cukai. (2020). Kajian Pengenaan Cukai Atas the Kombucha. Jakarta: Direktorat Teknis dan Fasilitas Cukai.

Elder, R.W., Lawrence, B., Ferguson, A. (2010). The Effectiveness of Tax Policy Intervention for Reducing Excessive Alcohol Consumption and Related Harms. Am J Prev Med. 2010 February; 38(2): 217-229.

Excise Duty Tables. Part I Alcoholic Beverages (2020). European Commission, Directorate General Taxation and Customs Union.

John, Stephen Moses \& Deeseenthum, Sirirat. (2015). Properties and benefits of kefir -A review. Songklanakarin J. Sci. Technol. 37 (3), 275-282, May-Jun. 2015.
Khamidah, Aniswatul \& Antarlina, S.S. (2020). Peluang Minuman Kombucha Sebagai Pangan Fungsional. Jurnal: Agrika: Jurnal Ilmu-Ilmu Pertanian, Volume 14, Nomor 2, November 2020: 184200.

Kementerian Keuangan. (2009). Peraturan Menteri Keuangan No 237/PMK.04/2009 Tentang Tidak Dipungut Cukai. Jakarta: Kementerian Keuangan Republik Indonesia.

Kementerian Keuangan. (2017). Buku Tarif Kepabeanan Indonesia Tahun 2017. Jakarta: Direktorat Jenderal Bea dan Cukai.

Kementerian Keuangan. (2018). Peraturan Menteri Keuangan No 158/PMK.010/2018 Tentang Tarif Cukai Etil Alkohol, Minuman Yang Mengandung Etil Alkohol, Dan Konsentrat Mengandung Etil Alkohol. Jakarta: Kementerian Keuangan Republik Indonesia.

Majelis Ulama Indonesia. (2018). Fatwa MUI Nomor 10 Tahun 2018 Tentang Produk Makanan dan Minuman yang Mengandung Alkohol/Etanol. Jakarta: MUI.

Millar Kreklewetz LLP. Tax and Trade Lawyers. Alcohol Taxes and Duties. Retrieved from https://www.taxandtradelaw.com/ alcoholtaxesandduties.html on May 23, 2021.

McIntyre, Lorraine \& Sik Jang, Sung. (2020). A Study of Alcohol Levels in Kombucha Product in British Columbia. Provincial Health Services Authority. BC Centre for Disease Control.

Ordonansi Cukai Alkohol Sulingan Stbl. 1924 No.351

Pemerintah Republik Indonesia. (2007). Undang-Undang Republik Indonesia Nomor 11 Tahun 1995 Tentang Cukai Sebagaimana 
Diubah Dengan Undang-Undang Republik Indonesia Nomor 39 Tahun 2007. Jakarta: Kementerian Hukum dan HAM.

Pratiwi, A. , Elfita \& Aryawati, R. (2011). Pengaruh Waktu Fermentasi Terhadap Sifat Fisik dan Kimia pada Pembuatan Minuman Kombucha dari Rumput Laut Sargassum sp. Fakultas Matematika dan Ilmu Pengetahuan Alam. Universitas Sriwijaya. Palembang.

Wikipedia. Kefir. Retrieved from https://en.wikipedia.org/wiki/ Kefir on February 2, 2021.

Wikipedia. Kombucha. Retrieved from https://en.wikipedia.org/wiki/ Kombucha on February 2, 2021.

https://www.tokopedia.com/hargamasker kefir/susu-kefir-sapi-1-liter-atau1000-ml-grosir-reseller-primaasli? refined $=$ true $\&$ whid $=0$ Penjualan online Kefir.

https://www.tokopedia.com/rekomendasi/ 1253172478?ref=googleshopping\& $\mathrm{c}=11975829286 \& \mathrm{~m}=287094937 \& \mathrm{p}$ $=1253172478 \&$ gclid $=$ Cj0KCQiA7 YyCBhD_ARIsALkj54pd0kHzL23 uu02QjchapmxveNIvLlM8xjiO3ch QfEoNPdeVDH9TSK8aAiHOEAL w $w c B \& g c l s r c=a w . d s$

Penjualan online Kombucha. https://www.ttb.gov/kombucha Perlakuan Kombucha di Amerika Serikat 
Vol. 5, No. 1, 2021

\section{LAMPIRAN}

Penjualan Minuman Kombucha pada Tokopedia

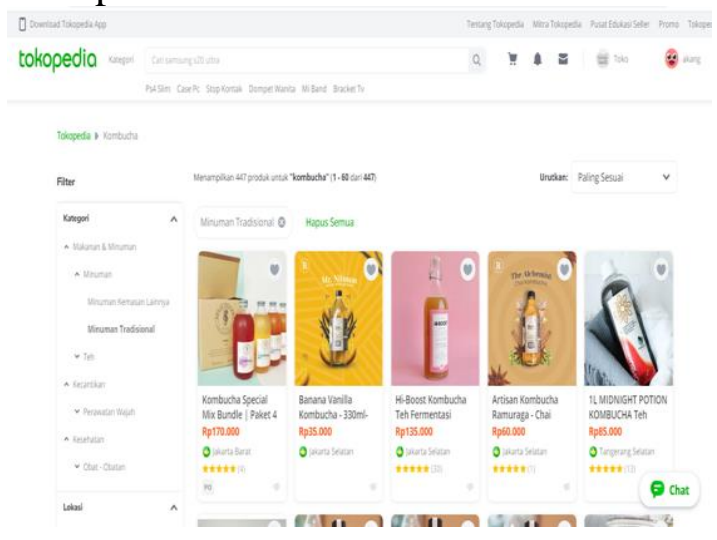

Penjualan Minuman Kombucha pada Bukalapak

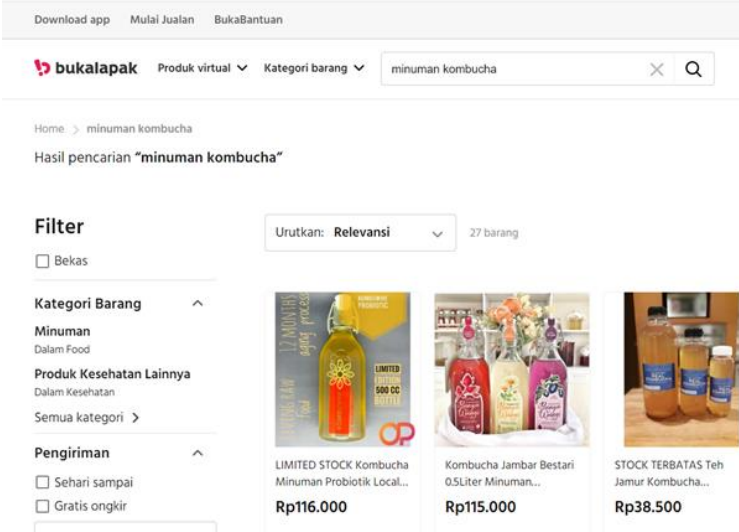

Penjualan Minuman Kombucha pada Lazada

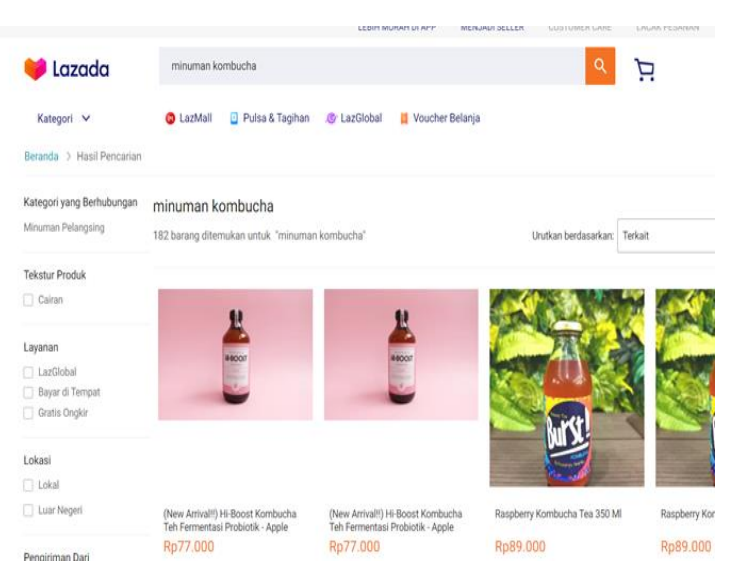

Penjualan Minuman Kombucha pada Shopee

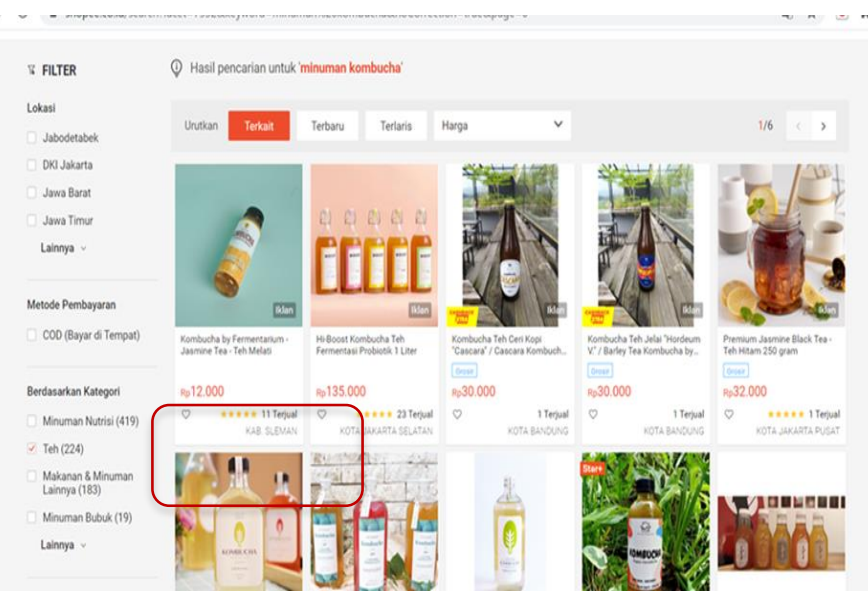

Penjualan Minuman Kombucha pada Blibli
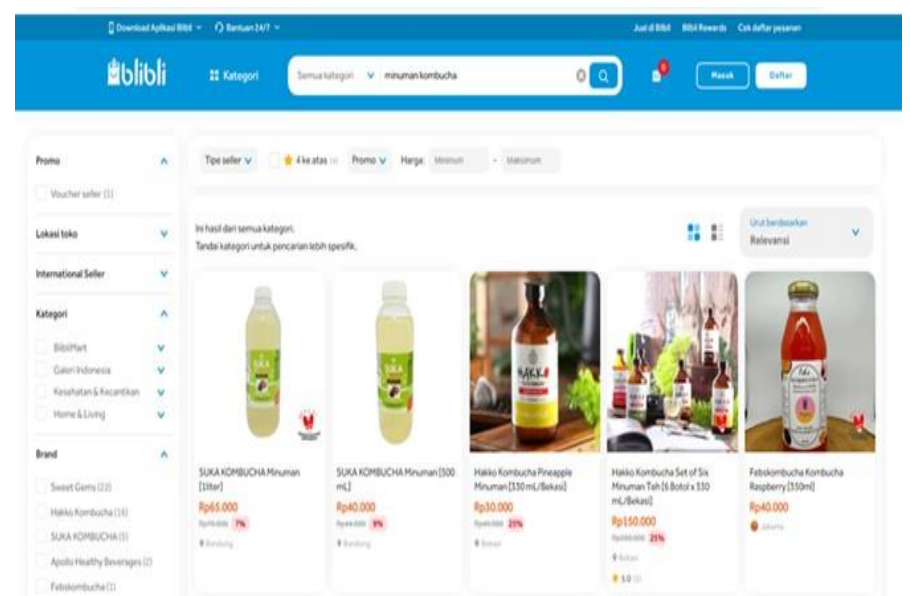

Penjualan Minuman Kefir pada Tokopedia 
Vol. 5, No. 1, 2021

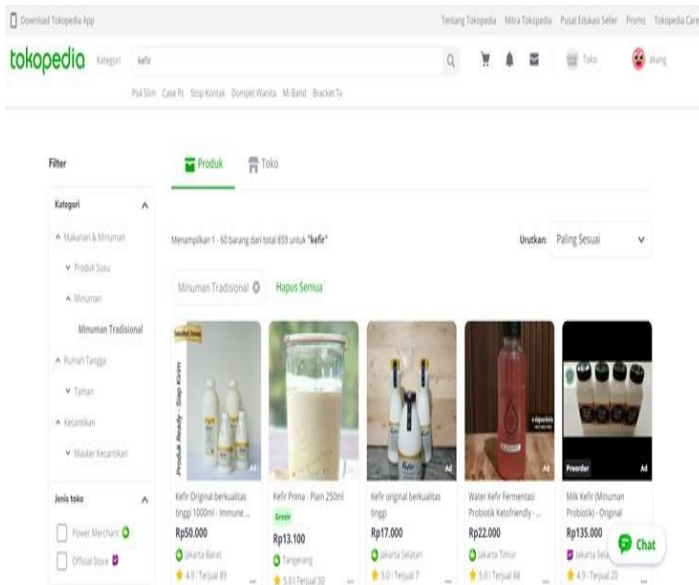

Penjualan Minuman Kefir pada Bukalapak

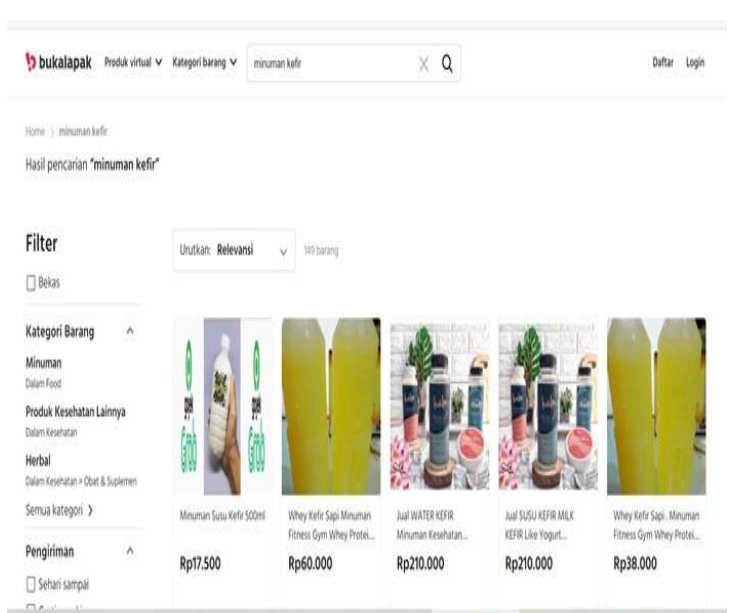

Penjualan Minuman Kefir pada Lazada

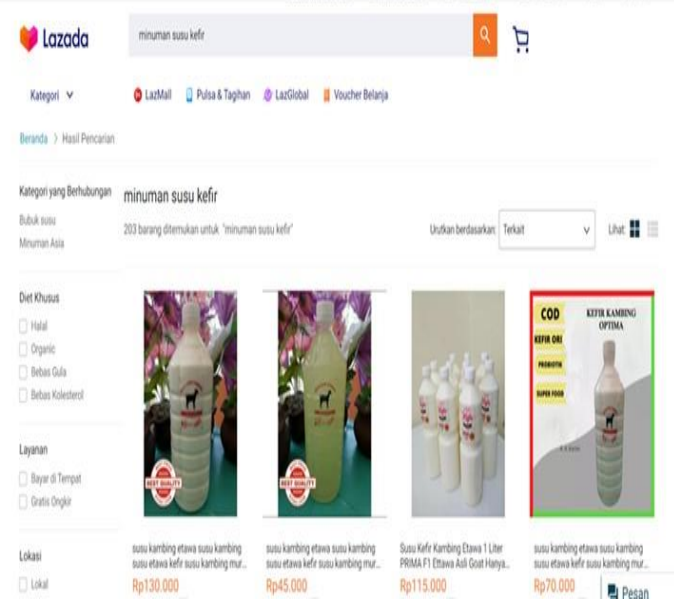

Penjualan Minuman Kefir pada Shopee

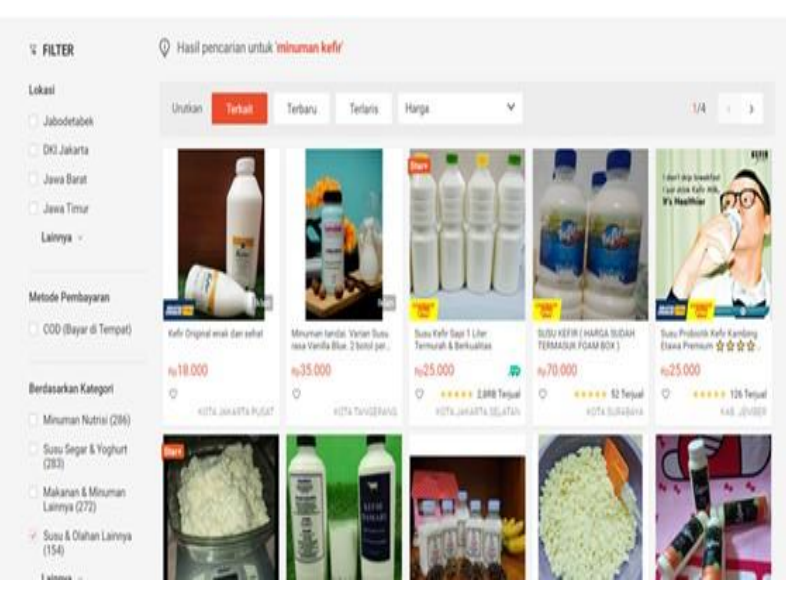

Penjualan Minuman Kefir pada Blibli
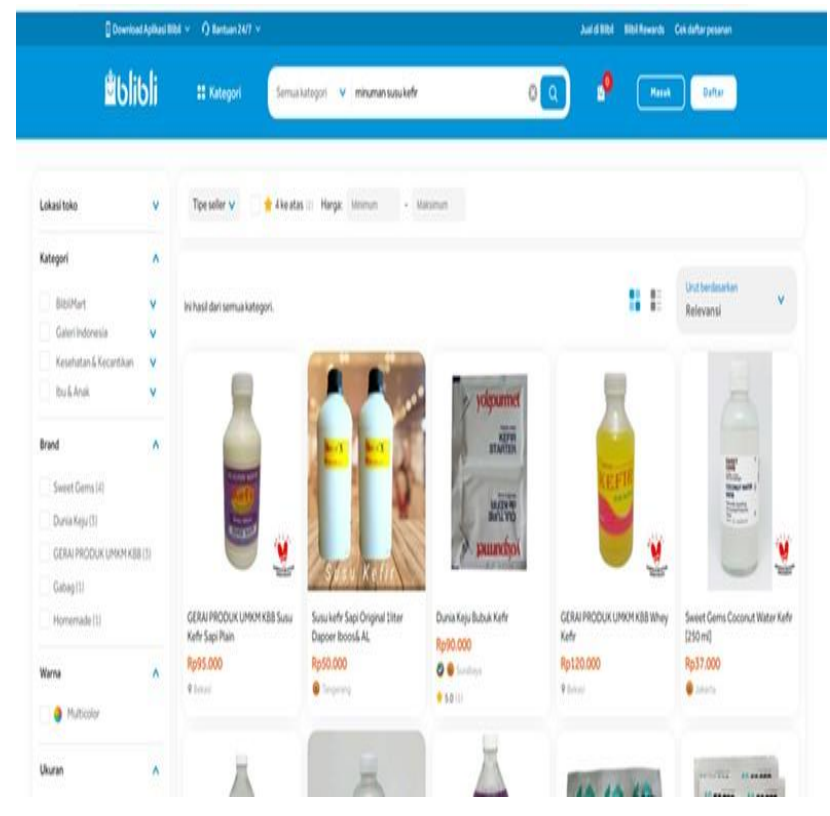